Boletim IG. Instituto de Geociências, USP, V.9:203-211, 1978

\title{
QUATERNARY SEDIMENTARY ENVIRONMENTS IN COMPRIDA ISLAND, STATE OF SĀO PAULO, BRAZIL *
}

\author{
By \\ Kenitiro SUGUIO \\ Departamento de Paleontologia e Estratigrafia \\ José H. BARCELOS \\ Setor de Geociências - Departamento de Genética e Evolução - Instituto de \\ Biologia - Universidade de Campinas - UNICAMP
}

\begin{abstract}
The coastal plain between the towns of Cananéia and Iguape is very important as it contains the most extensive Quaternary coastal sedimentation in the State of São Paulo, Brazil. Comprida Island, the most prominent physiographic feature in this geological context, is essentially formed of shallow marine sands.

Sedimentological analysis made it possible to characterize the texture and mineralogy of 126 samples of sediments from the different sub-environments of Comprida Island. Grain size analysis of the sands, treated by the SAHU method (1964), indicates high-energy and low-viscosity deposition in beach, shallow marine and eolian environments. Morphometric and heavy-mineral studies suggest that Holocene sands are derived from the Cananéia Formation (Pleistocene), the Precambrian Crystalline Complex, and the Upper Precambrian Açungui Group.

The combined foraminiferal content of 26 of the samples consists of twenty-six species belonging to twenty-one genera, where Ammonia beccarii (Linné) and Nonionella atlantica (Cushman) are the dominant species. Data on these micro-organisms emphasize the importance of foraminifera in the interpretation of beach zone dynamics and show the necessity of considering the relations of these assemblages to the pattern of circulation of water masses and to such biological controls as the ecological succession of benthonic communities.
\end{abstract}

\section{RESUMO}

A planície costeira entre as cidades de Cananéia e Iguape é muito importante porque ela contém a sedimentação quaternária mais extensa do litoral do Estado de São Paulo, Brasil. Ilha Comprida, a mais proeminente feição fisiográfica nèste contexto geológico, é essencialmente formada de areias de ambiente marinho raso.

Análises sedimentológicas tornaram possível a caracterização da textura e mineralogia de 126 amostras de sedimentos de diferentes subambientes da Ilha Comprida. Os resultados das análises granulométricas de areias, tratados pelo método de SAHU (1964), indicaram deposição em ambiente praial, marinho raso e eólico de alta energia e baixa viscosidade. Estudos morfométricos e de minerais pesados de areias do Holoceno sugerem uma fonte múltipla relacionada à Formação Cananéia (Pleistoceno), ao Complexo Cristalino do Precambriano e às rochas do Grupo Açungui do Precambriano Superior.

* Presented at the X International Congress of the INQUA in Birmingham (England). 
O conteúdo em foraminíferos de 26 amostras mencionadas acima indicou a presença de vinte e seis espécies pertencentes a vinte e um gêneros, onde Ammonia beccarii (Linné) e Nontonella atlantica (Cushman) foram as espécies dominantes. Os dados obtidos enfatizam a importância dos foraminíferos na interpretação da dinâmica de zonas praiais e mostram a necessidade de se considerar essas assembléias em relação à circulação das águas e não apenas a controles biológicos, tal como o nível de maturidade evolutiva das comunidades bentônicas.

\section{INTROCUTION}

The littoral of the State of São Paulo is characterized by a series of more or less extensive sedimentary plains separated from each other by headlands of Crystalline Basement that reach the sea.

The coastal plains, from the north southward, are named Caraguatatuba, Bertioga, Santos, Itanhaem and Cananéia-Iguape. The sediments of the coastal plains were laid down in shallow marine environments throughout the two most important Pleistocene and Holocene transgressive phases. They are extensively distributed in the southern half of the littoral, becoming less and less important northward.

The coast of the State of São Paulo exhibits two very different aspects limited by the Bertioga region. The southwestern half shows emergent characteristics and is formed by well developed Quaternary marine formations (SUGUIO and MARTIN, 1975).

This coast, which is not absolutely stable, was probably tectonically active during most of the Quaternary, although a tectonic influence has been of only minor importance in recent Quaternary sedimentation. During this phase the sedimentation of the Comprida Island took place.

The authors wish to express their sincere thanks to the "Fundação de Amparo à Pesquisa do Estado de São Paulo (FAPESP)" for financial support (Geologia 73/074) and to Dr. Thomas R. Fairchild for revis: a of the English text.

\section{COMPRIDA ISLAND}

Comprida Island stretches from north of the Ribeira de Iguape River to the Ararapira Outlet and is a part of the Cananéia-Iguape lagoonal region at the boundary of the States of São Paulo and Paraná (Fig. 1). It is 70 km long, ranges from 2 to $5 \mathrm{~km}$ in width, and comprises a flat surface 2 to $4 \mathrm{~m}$ above the average present sea-level. Beach-ridges are the dominant morphological features of the island's surface. A small hill (given the name Morrete), $42 \mathrm{~m}$ high and composed of alkaline rocks, is situated at its southwestern tip.

The island is separated from the continent by the "Pequeno sea" or "Iguape sea", 400 to $1,200 \mathrm{~m}$ wide. Southward this "sea" diverges around Cananéia Island with one branch called the "Cananéia sea" or "Fora sea" and the other the "Cubatão sea" or "Dentro sea".

Slightly beyond the southern end of Comprida Island is Cardoso Island, separated from Cananéia Island by Trapandé Bay. Iguape Island, at the northern extremity of Comprida Island, is artificial and originated with the opening of the "Valo Grande", a channel connecting the Ribeira de Iguape River to the "Pequeno sea".

The most important beach of Comprida Island is the "Praia de Fora" situated at the oceanside, and almost $70 \mathrm{~km}$ long. This beach is characterized by a very gently sloping surface due to its very fine-grained, well-sorted sands. At the southwestern tip of Comprida Island, the "Praia do Pontal" is characterized by high energy waves acting on coarse-grained sands.

Also on Comprida Island's oceanside are well developed dunes formed by dry sands blown from high tidal and supratidal zones. The highest of these are in the southern region of the island, reach $7 \mathrm{~m}$ in height, and are distributed across a belt 100 to $200 \mathrm{~m}$ wide. These dunes are beach ridges reworked on surface by the winds. 
The valleys between the beach-ridges are occupied by more or less ephemeral streams characterized by their unstable courses and stagnant water swamps.

The different geological formations of Comprida Island were recently described by MARTIN and SUGUIO (1975). At the base of the sequence, coarse-grained sands and conglomerates, in contact with the Crystalline Basement, can be correlated with BIGARELLA and MOUSINHO's (1965) Pariquera-Açu Formation. This continental formation, Pliocene in age, was reached through a drill hole in the beach (Praia de Fora). The Cananéia Formation (SUGUIO and PETRI, 1973), which probably originated before the last Holocene transgression, occupies a great part of the region, abutting against the Crystalline Basement rocks, where it is locally covered by more recent continental formations. Holocene marine and transitional formations are located topographically below outcrops of the Cananéia Formation.

\section{SEDIMENTOLOGY}

\section{Sampling}

The sedimentological characterization of Comprida Island and its environs is based on 126 samples distributed across 15 sections (low tide and high tide levels, beach-ridges and dunes) and 4 linear sampling series throughout the island. The purpose of this survey is to correlate the regional trend of the sedimentological parameters with depositional sub-environments of Comprida Island.

\section{Grain size}

As previously observed by SUGUIO and PETRI (1973), who analysed bottom sediments of Comprida Island's environs (lagoonal area), the sand samples here studied show remarkable uniformity. Of 123 samples subjected to grain size analysis and statistically treated according to the method of FOLK and WARD (1957), 12 samples presented mean diameters in the very fine sand class ( 3 to $4 \phi$ ) and 111 samples in the fine sand class ( 2 to $3 \phi)$. This parameter revealed a regional fining-northward pattern.

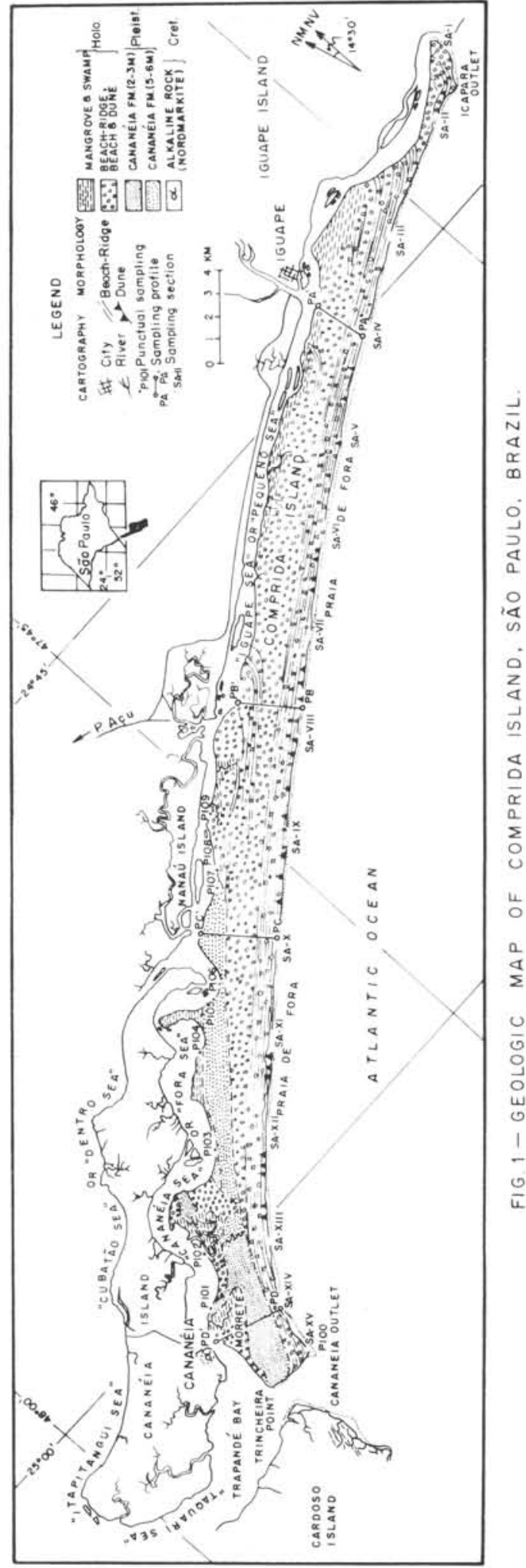


Standard deviation of grain size frequencies indicates that $75 \%$ of the samples are very well-sorted, $19 \%$ well-sorted, and $6 \%$ moderately sorted sands. The last group is represented by samples from the southern tip of the island and from the mouth of the Ribeira de Iguape River. The analysed samples showed that the better sorted sands are found in the north of the island.

The dominant values of skewness and kurtosis ranged from almost symmetrical (48\%) to positive skewness (36\%) and mesokurtic (46\%) to leptokurtic (35\%), respectively.

The relationships between energy, viscosity and depositional environments which are determinable from the grain size frequencies of the samples were characterized by the method of SAHU (1964).

Fig. 2 shows that the sub-environments have similar viscosities, but different energies (groups I to XVIII).

Groups I to VIII, XIX and XX, respectively representing samples from low-tide and high-tide regions, exhibit low viscosity and moderate energy, thus indicating shallow marine to beach sand deposits, as expected. Group XXI, representing samples from high tidal regions, shows evidences of increased energy but is also characteristic of shallow-marine to beach environments of viscosities similar to those of the previous groups but with slightly higher energy levels.

Group XXIII defined by all the samples collected from the top and shallow subsurface (less than $1 \mathrm{~m}$ ) of the beach-ridges showed energy and low-viscosity indicating a shallow-marine environment. The samples from the tops of the beach-ridges (group XXIV) indicate shallow-marine to beach environments. It is probable that there has been a little reworking of the beach-ridges surfaces by the wind. The shallow subsurface (less than $1 \mathrm{~m}$ ) samples (group XXV) from the beach-ridges presented low-viscosity and a lower energy than group XXIV, indicating typical shallow-marine sand.

Several sub environments of Comprida Island and its environs are presently subjected to continuous reworking, but as the sands have

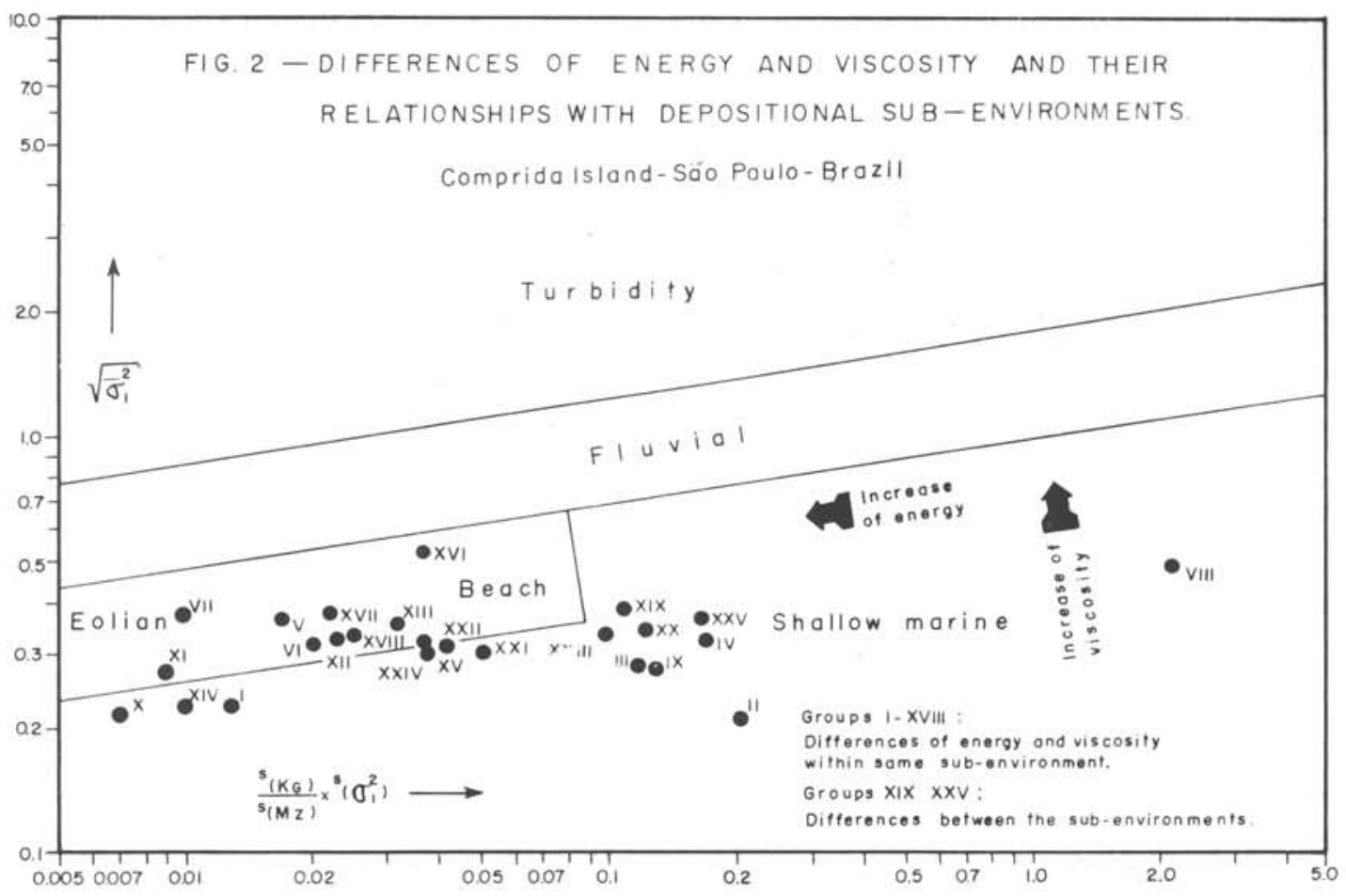




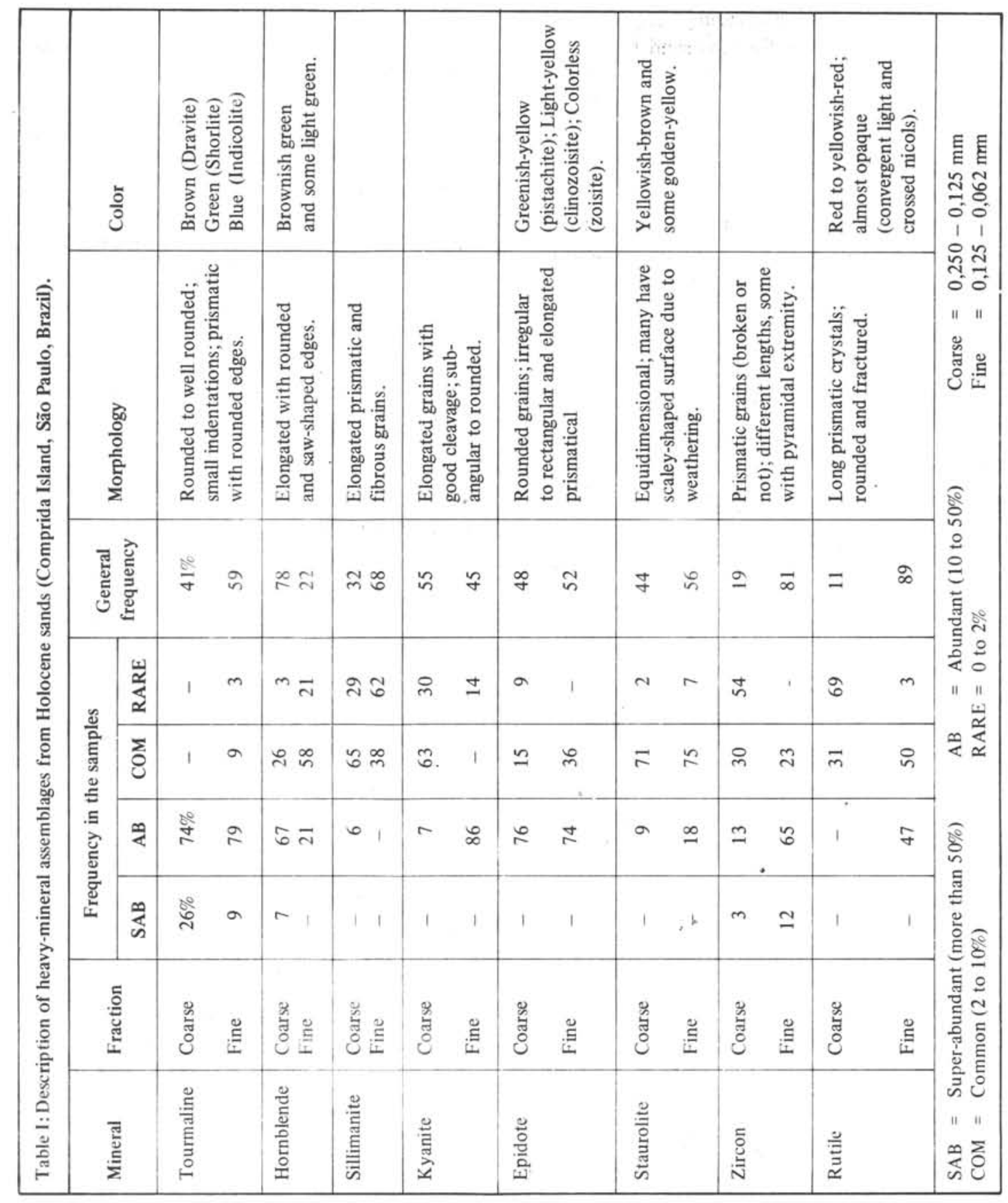

attained very high maturity, only slight sedimentological changes are observable as a result of this reworking.

\section{Heavy minerals}

The heavy minerals of the fine sand ( 2 to $3 \phi$ ) and very fine sand ( 3 to $4 \phi$ ) fractions of thirty-three samples representing Comprida Island and its environs were studied.

Eight non-micaceous, transparent minerals were identified in the samples: epidote, hornblende, kyanite, rutile, sillimanite, staurolite, tourmaline and zircon (Table I). 
The order of decreasing frequency of the heavy minerals in the fine sand fraction is as follows: tourmaline, epidote, zircon, staurolite, sillimanite, kyanite and rutile. Other, very rare minerals in this fraction are: andalusite, garnet, ittanite, anatase, apatite, hypersthene and dumortierite.

Some minerals that are less frequent in the fine sand fraction may be more abundant in the very fine sand fraction. For example, in order of decreasing frequency, the observed heavy-minerals in this fraction are tourmaline, zircon, epidote, rutile, staurolite, hornblende, kyanite and sillimanite, with very rare andalusite, garnet and titanite.

The heavy-minerals present in both fractions of all the samples are tourmaline, epidote and staurolite. Sillimanite occurred in all samples of fine sand and zircon in all samples of very fine sand.

The heavy mineral composition of the sediments is related to the regional geology. Kyanite, staurolite and sillimanite were furnished by the metasedimentary Açungui Group. The source-rocks of tourmaline, hornblende, epidote, zircon, rutile, titanite, hypersthene, monazite and apatite probably are the migmatites and granites of the Crystalline Complex. The original source-rocks of both the Cananéia Formation (Pleistocene) and the Holocene deposits of Comprida Island are these Precambrian rocks.

Different degrees of roundness noted for the same mineral are indicative of more than one source for the Holocene deposits. High degrees of roundness may be correlated with the Cananéia Formation as a source rock, whereas low degrees of roundness are indicative of direct erosion from Precambrian sources.

\section{FORAMINIFERA CONTENT AND ITS ECOLOGICAL SIGNIFICANCE}

Twenty-six samples analysed for their foraminiferal content indicate intertidal zone sub-environments (mangrove, beach and sand bars). The foraminiferal assemblages are interpreted as typical of benthonic communities of the intertidal zone.
This study suggests a further application of paleoecological studies for the determination of paleostrandlines in older marine sediments.

Twenty-six species belonging to twentyone genera were identified (Table II), with Ammonia beccarii (Linné) and Nonionella atlantica (Cushman) the dominant species. All the identified species have been referred to in previous Brazilian littoral studies. The samples are characterized by reduced values of relative frequency $c f$ specimens and species diversity.

This association is different from that found on the beaches of the Santos estuary but is similar to the assemblage studied by SUGUIO et al. (1975) in the Santos Bay area. These differences may be controlled by local dynamics of the water masses. In the beaches of Santos estuary the sedimentological behavior of the foraminifera may be as inorganic sedimentary particles, and, where water-depth exceeds $6 \mathrm{~m}$, the foraminiferal assemblages are associations of living forms. With this in mind, it is possible to interpret the foraminiferal assemblages of Comprida Island as being more similar to associations of living forms than to death assemblages.

Small, thin-walled foraminifera, probably representing younger individuals, are the dominant forms. In terms of foraminiferal dimensions, this situation is different both from that of the zone of turbulence (PHLEGER, 1960), and from that for the beaches and bay of Santos, State of São Paulo (PETRI and VIEIRA, oral communication). According to these authors, relative frequency of specimens and species diversity in assemblages of transported foraminifera may have high or low values, the essential control being the circulation of water masses.

As expected, planktonic foraminifera are scarce, and this may be explained by the effect of the shoreline on the turbidity and salinity of the wațer masses. The assemblage studied here comprises an association of dead benthonic foraminifera; some thecamoeba occurs in associations collected at low tide. 


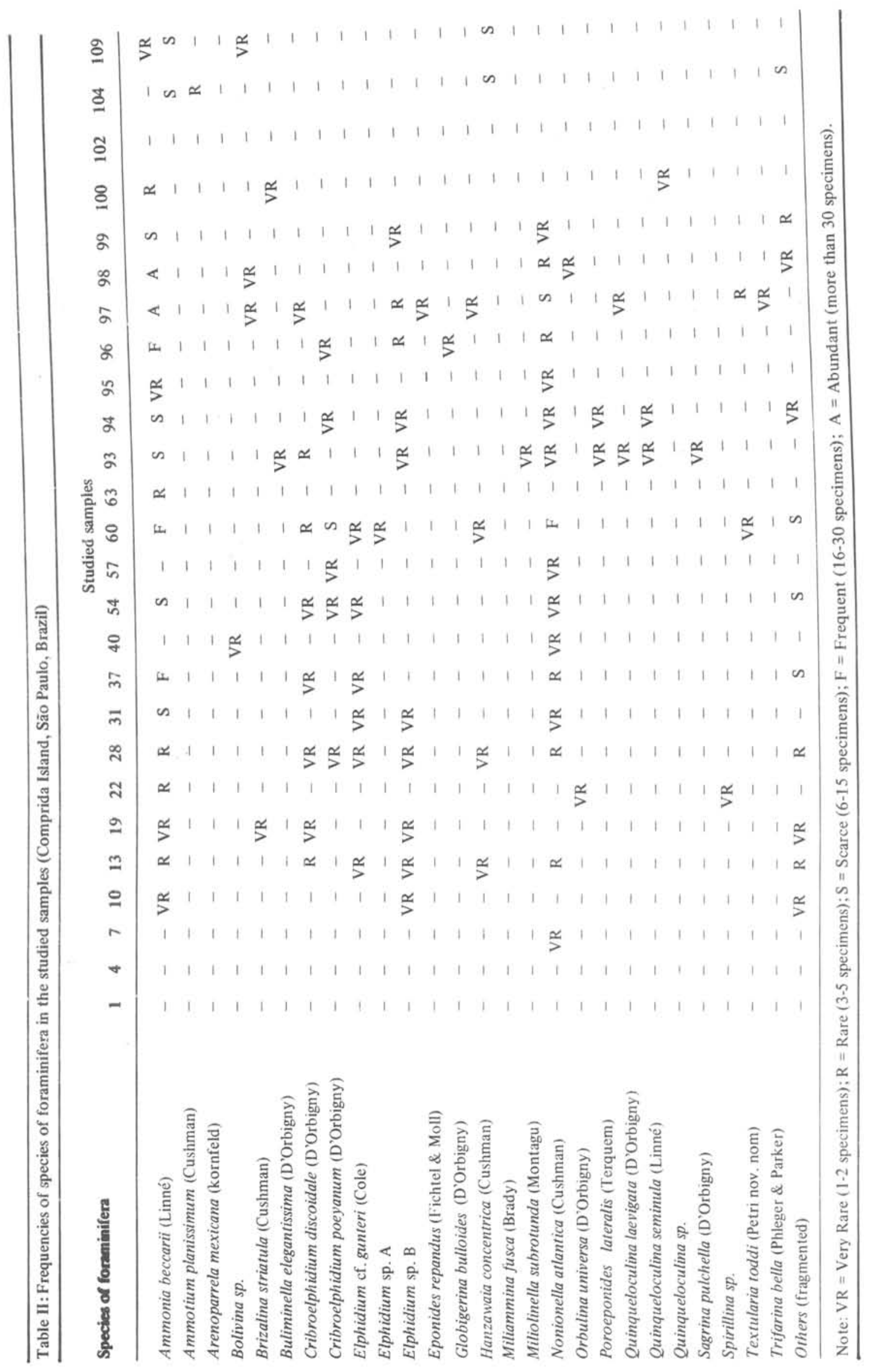




\section{HOLOCENE SEA-LEVEL CHANGES AND THE ORIGIN OF COMPRIDA ISLAND}

SUGUIO et al. (1976) delineated the Holocene sea-level fluctuation curve for the past 6,000 years for the Cananéia-Iguape area. Mean sea-level has been subjected to several oscillations during this period. The sea-level 6,200 years B.P. was near the present one. The first maximum occurred 5,000 years 3.P. when the average sea-level was $4.5 \mathrm{~m}$ higher than present in some places. This first maximum was followed 3,800 years ago by a minimum when the sea-level was a little lower than present. At 3,200 years B.P. a second maximum occurred when the sea-level was $3 \mathrm{~m}$ higher than present. Finally, it appears likely that a sea-level near the present one has been maintained for the last 1,800 years.

Comprida Island has an estimated total area of $300 \mathrm{~km}^{2}$. More than $250 \mathrm{~km}^{2}$, that is more than $5 / 6$ of the island, is made up of Holocene sediments formed during the past 6,000 years. About $1 / 6$ is made up of the Pleistocene Cananéia Formation, which locally has been eroded into wave-cut terraces, at the southwestern tip of the island.

\section{CONCLUSIONS}

Comprida Island is composed of the Pleistocene Cananéia Formation $\left(50 \mathrm{~km}^{2}\right)$, cropping out in the SW, with the rest of the island formed by Holocene beach-ridge sands $\left(207 \mathrm{~km}^{2}\right)$, that has been locally reworked by wind $\left(11 \mathrm{~km}^{2}\right)$ or form limited areas of swamps and mangroves $\left(32 \mathrm{~km}^{2}\right)$.

The most important source rock for Holocene sediments is the Cananéia Formation, with some contribution from Precambrian rocks. Holocene sediments have very homogeneous grain sizes, a characteristic inherited from the Cananéia Formation, and thus only slight changes are noted when they are reworked and redeposited.

Longshore-drift-currents, presently active in the northward growth of Comprida Island (30m/year), have also been very important since the island first formed 6,000 years ago. This is suggested by the changes in grain-size parameters from $\mathrm{S}$ to $\mathrm{N}$. After the second transgressive maximum (about 3,200 years ago) the island was subjected to a process of enlargement related to a regressive phase that is still active today. Shell-middens on the first Holocene beach-ridge contain abundant whale bones that are suggestive of the proximity of the shoreline in the past. Radiocarbon dating of material from these middens indicates an age of $3,090 \pm 110$ years B.P., which is probably when Comprida Island began to enlarge.

\section{BIBLIOGRAPHY}

BIGARElla, J.J. and MOUSINHO, M.R. (1965) - Contribuição ao Estudo da Formação Pariquera-Açu (Estado de São Paulo) - Bol. Paran. Geogr. no 16/17:17-41, Curitiba, PR.

FOLK, R.L. and WARD, W.C. (1957) - Brazos River Bar: A Study in the Significance of Grain Size Parameters Journ. Sedim. Petrol., $28: 3-26$.

MARTIN, L. and SUGUIO, K. (1975) - The State of São Paulo Coastal Marine Quaternary Geology - The Ancient Strandlines - Bol. Paran. Geociênc. no 33:18 (abstract), in press (Proceedings of the Intern. Symp. on the Quaternary, Curitiba, PR).

PHLEGER, F.B. (1960) - Ecology of Foraminifera in South Eastern Mississipi Delta Area - Amer. Assoc. Petrol. Geol. 39(5).

SAHU, B.K. (1964) - Depositional Mechanisms from the Size Analysis of Clastic Sediments - Jour. Sed. Petrol., 34:73-83.

SUGUIO, K. and PETRI, S. (1973) - Stratigraphy of the Iguape-Cananéia Lagoonal Region Sedimentary Deposits, São Paulo State, Brazil. Part I: Field Observations and Grain Size Analysis - Bol. IG, Instituto de Geociênc./ USP, vol. 4:1-20, São Paulo. 
SUGUIO, K. and MARTIN, L. (1975) - Brazilian Coastline Quaternary Formations - The States of São Paulo and Bahia Littoral Zone Evolutive Schemes - Intern. Symp. on Continental Margins of Atlantic Type, Oct. 1975 (São Paulo); Anais Acad. Bras. Ciênc. (1976), 48 (Suplemento): 325-334.

SUGUIO, K.; VIEIRA, E.M. and BARCELOS, J.H. (1975) - Ecological Interpretations of the Foraminifera from the Santos Estuary Zone, State of São Paulo, Brazil - Bol. Paran. Geociênc. no 33: 41 (abstract), in press (Proceedings of the Intern. Symp. on the Quaternary, Curitiba, PR).

SUGUIO, K.; MARTIN, L. and FLEXOR, J.M. (1976) - Les Variations Rélatives du Niveau Moyen de la Mer au Quatérnaire Récent dans la Région de Cananéia-Iguape (São Paulo) - Bol. IG, Instituto de Geociênc./USP, vol. 7:113-129, São Paulo. 